African Crop Science Journal by African Crop Science Society is licensed under a Creative Commons Attribution 3.0 Uganda License. Based on a work at www.ajol.info/ and www.bioline.org.br/cs DOI: http://dx.doi.org/10.4314/acsj.v24i1.16S

\title{
WEED FLORA OF CASSAVA IN WEST NILE ZONES OF UGANDA
}

\author{
R. KAWOOYA, S. WAMANI ${ }^{1}$, S. MAGAMBO ${ }^{2}$ and R. NALUGO \\ National Crops Resources Research Institute (NaCRRI), P. O. Box 7084, Kampala, Uganda \\ ${ }^{1}$ Ngetta Zonal Agricultural Research and Development Institute, P. O. Box 52, Lira, Uganda \\ ${ }^{2}$ Bulindi Zonal Agricultural Research and Development Institute, P. O. Box 101, Hoima, Uganda \\ ${ }^{3}$ Abi Zonal Agricultural Research and Development Institute, P. O. Box 219, Arua, Uganda \\ Corresponding author: kawoox@yahoo.co.uk
}

\begin{abstract}
Information on weeds of cassava (Manihot esculenta Crantz) in eastern Africa is limited. The objective of this study was to establish the status of weed flora in selected cassava growing regions of Uganda. This study was conducted in 2013 at Abi Zonal Agricultural Research and Development Institute; (AbiZARDI) in Arua, Ngetta Zonal Agricultural Research and Development Institute (NgeZARDI) in Lira, and Bulindi Zonal Agricultural Research and Development Institute (Bulindi ZARDI) in Hoima, all in Uganda. Weed densities were estimated from twelve quadrant samples taken systematically along diagonal transects, in 27 cassava fields. Grass weed species were the most frequent, averaging $55.01 \%$ of the entire weed species. Five weed species namely, Digitaria abyssinica (African couch grass), Imperata cylindrica (Spear gras), Commelina benghalensis (Wandering Jew), Panicum maximum (Guinea grass) and Ageratum conyzoides (Goat weed or White weed or Chick weed), predominated the study areas.
\end{abstract}

Key Words: Digitaria, Imperata, Manihot esculenta

\section{RÉSUMÉ}

Les informations sur les mauvaises herbes de cassave (Manihot esculenta Crantz) dans l'Afrique de l'est sont limitées. L'objectif de cette étude était d'établir le statut de flore de mauvaise herbe dans la cassave choisie cultivant des régions de l'Ouganda. Cette étude a été accomplie en 2013 à l'Institut de Développement et de Recherche Agricole Zonal Abi; (AbiZARDI) dans Arua, Ngetta l'Institut de Développement et de Recherche Agricole Zonal (NgeZARDI) en Lire et Institut de Développement et de Recherche Agricole Zonal Bulindi (Bulindi ZARDI) dans Hoima, tous en Ouganda. Les densités de mauvaise herbe ont été estimées de douze échantillons de quadrant pris systématiquement le long de la diagonale transects, dans 27 champs de cassave. Les espèces de mauvaise herbe d'herbe étaient les plus fréquentes, en faisant en moyenne $55.01 \%$ des espèces de mauvaise herbe entières. Cinq espèces de mauvaise herbe à savoir, Digitaria abyssinica (le chiendent africain), Imperata cylindrica (la Lance gras), Commelina benghalensis (le Juif se Promenant), Panicum maximum (l'herbe de Guinée) et Ageratum conyzoides (la mauvaise herbe de Chèvre ou la mauvaise herbe Blanche ou la mauvaise herbe de Poussin), ont prédominé les régions d'étude.

Mots Clés: Digitaria, Imperata, Manihot esculenta

\section{INTRODUCTION}

Weeds in Uganda, like in the rest of Africa are a key recalcitrant of all crop pests proliferating each year on every farm. Weed seeds are very vital in the life cycle of annual or perennial weed species that reproduces through seed alone (Gulden and Shirtliffe, 2009). The quality and quantity of weed 
seeds in the soil bank determines the weed situation in a given farming system (Adesina $e t$ al., 2012).

Weeds compete with cultivated food crops for limited resources such as water, nutrients and light (Oudhia, 2004). Weed infestations also encourage disease problems, serve as alternate host for deleterious insects and diseases, slows down harvesting operation, increase the cost of production, reduce the market value of crops; and increase the risk of fire in perennial crops, plantation and forest reserves (Oudhia, 2004).

Weeds grow more vigorously and regenerate more quickly because of the heat and high light intensity (Benoit et al., 2004). High humidity and high temperature that are characteristic of subSaharan Africa, favour rapid and excessive weed growth (Akobundu, 1980).

African soils contain 100 to 300 million buried weed seeds per hectare, of which a fraction germinate and emerge each year. Over 286 species of common weeds have been identified in crop fields in some West African countries (Njoku, 1996). The nature of crop, cultural practices and cropping pattern/system, soil type, moisture availability, location and season have been reported to cause variation in the abundance or distribution of weed species that are found in a cropped field (Mohler, 2001; Sit et al., 2007). In Uganda and the rest of eastern Africa, limited information exists on the weed flora in cassava fields, yet they are a major obstacle to cassava productivity. The objective of this study was to document the status of weed flora in selected cassava growing regions of Uganda, as a basis for designing interventions for sustainable weed control.

\section{MATERIALS}

The study was conducted at three Zonal Agricultural Research Development Institutes (ZARDIs) namely; AbiZARDI in Arua, NgeZARDI in Lira and Bulindi ZARDI in Hoima all in Uganda, during the second cropping season of 2013. Weed densities were estimated from quadrant of [ $1 \mathrm{~m} \times 1 \mathrm{~m}]$ with 5 samples taken randomly and systematically along diagonal transects in each cassava field. Twelve quadrant samples were taken per hectare.
The area surveyed was 4.7 hectares from each of the survey ZARDI. A total of 27 cassava fields, with field sizes of 0.5 acres were considered in this study. The total number of weed species was recorded. Broad leaved and grasses weeds were, separately, counted per quadrant. Common names of different weeds were obtained from communities and recorded with their respective numbers. Data showing the relative frequencies of weeds were analysed using GenStat $14^{\text {th }}$ Edition statistical package. Significant means were separated using Least Significant Difference (Fisher's LSD) at 5\% probability level.

\section{RESULTS AND DISCUSSION}

Grass weed species were dominant in all the study areas, averaging $55.01 \%$ of the entire weed species recorded; the rest (45\%) were broad-leafed species (Fig. 1). These results could be due to the fact that the land had been uncultivated for years before the experiment and the grass weed flux species growing on that location were released on the soil without any human interference. In addition, this could be as a result of cassava architecture and canopy (spreading cassava variety) effect, which might have provided a more favourable or enabling environment to grass weeds than the broadleafed species, thus the high frequencies of grass weeds (Adesina et al., 2012). On the contrary, similar studies conducted in South Western Nigeria, Onochie (1975) observed that annual weeds especially broad leaved ones were the most common in cassava fields.

Five weed species, namely Digitaria abyssinica (African couch grass), Imperata cylindrica (Spear grass), Commelina benghalensis (Wandering Jew), Panicum maximum (Guinea grass) and Ageratum conyzoides (Goat weed or White weed or Chick weed), occurred in the entire area surveyed at the three ZARDIs (Fig. 2). In this study, $83 \%$ of weed population was Digitaria abysinica (African couch grass), 23\% was Imperata cylindrica (Spear grass), 50\% was Commelina benghalensis (Wandering Jew), 24\% was Panicum maximum (Guinea grass) and $7 \%$ was Ageratum conyzoides (Goat weed or White weed or Chick weed). 


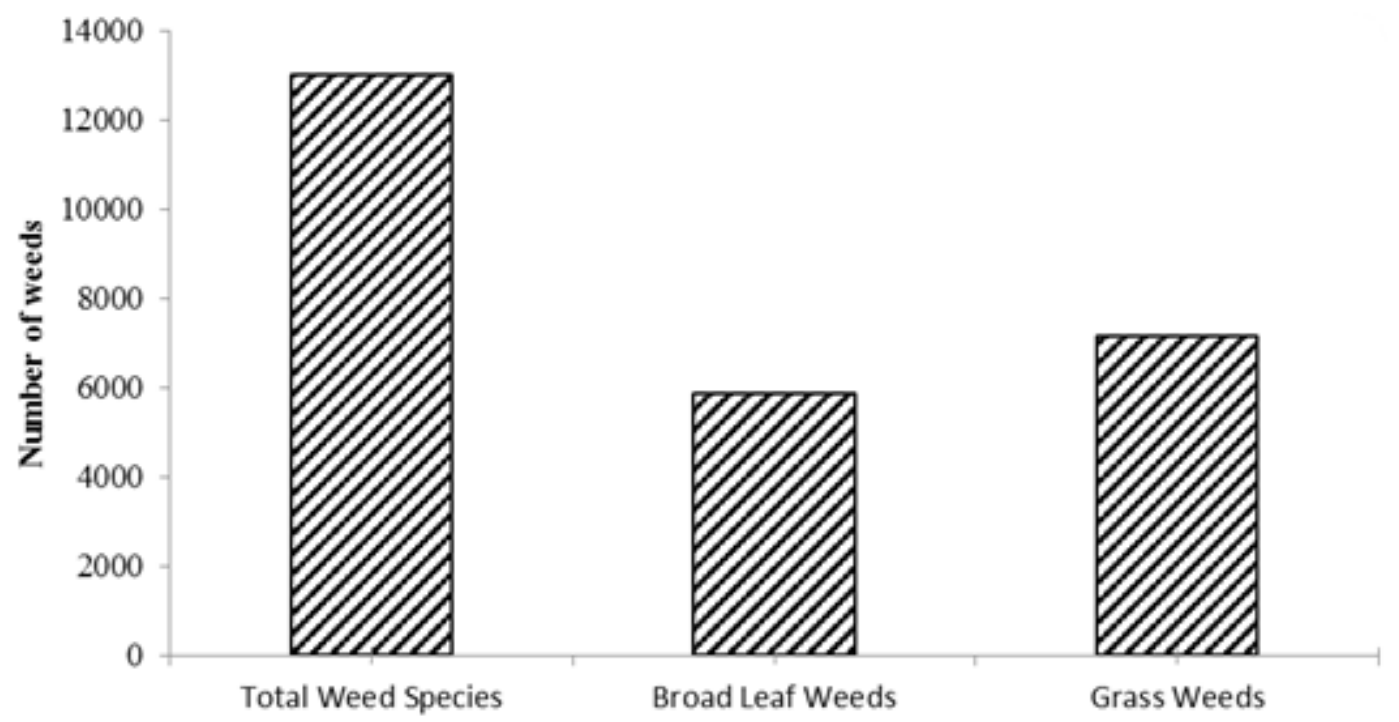

Figure 1. Total frequency of weeds number per acre prevalent in cassava fields in northern, mid-western and west Nile regions of Uganda.

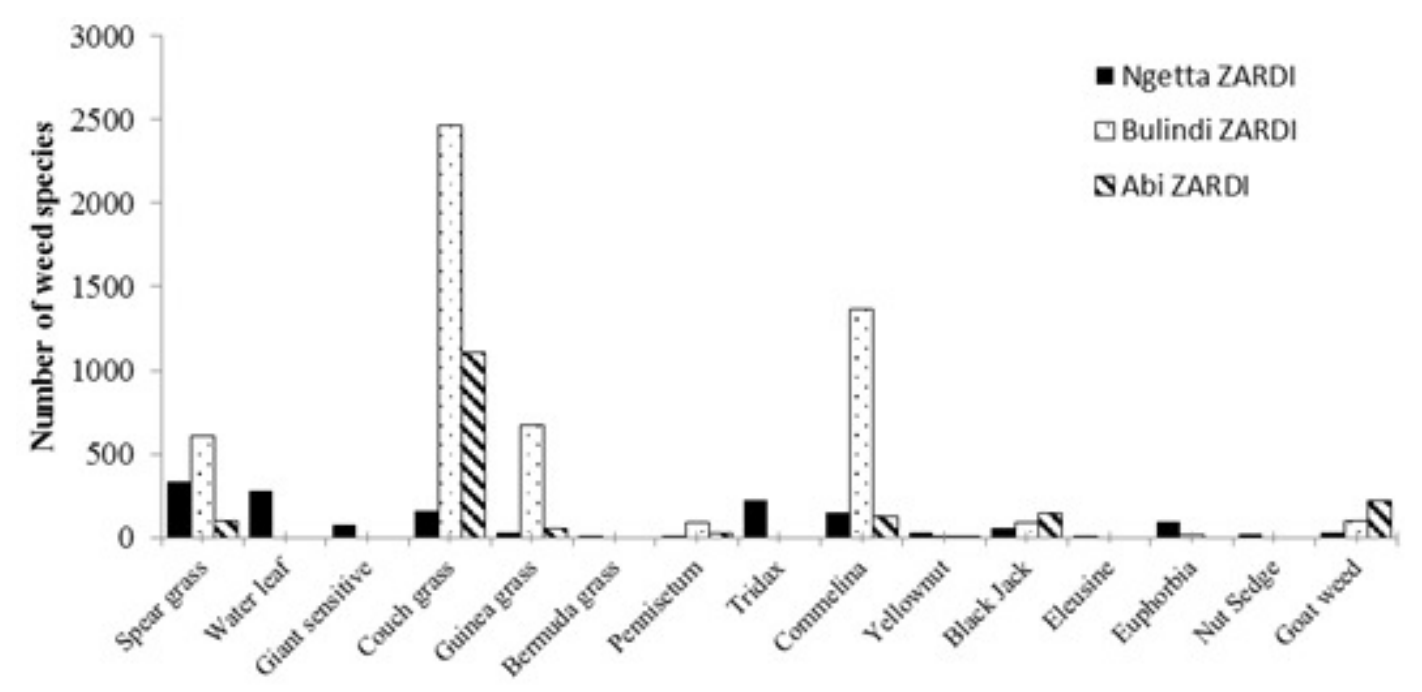

Figure 2. Proportion of weed species in cassava fields in northern, mid-western and west Nile regions of Uganda.

The other weed species varied from one ZARDI to the other. Most of the weeds recorded were among those regarded as "the world's worst" (Melifonwu, 1994). The presence of some weeds in almost all study areas indicates that their growth and development can occur under different light conditions, while restriction of some weeds to particular areas shows their requirement for special conditions for their survival (Adesina et al., 2012).

\section{CONCLUSION}

This should form the basis for selection of feasible and safe options for control of cassava weeds.

\section{ACKNOWLEDGEMENT}

Authors are grateful to the Eastern Africa Agricultural Productivity Project (EAAPP) and the National Agricultural Research Organization 
(NARO) in Uganda for the financial support provided and the Association for Strengthening Agricultural Research in Eastern and Central Africa (ASARECA) facilitated the publication of this paper.

\section{REFERENCES}

Adesina, G.O., Akinyemiju, O.A. and Ola, O.T. 2012. Assessment of frequency, density and abundance of weed species in different Cropping systems. Journal of Natural Sciences Research 2(9): 107-119.

Akobundu, I.O. 1980. Weed control in cassava cultivation in the sub-humid tropics. Tropical Pest Management 26:420-426.

Benoit, D.L., Kenkel, N.C. and Cavers, P.B. 2004. Factors inûuencing the precision of soil seed bank estimate. Canadian Journal of Botany 67: 2833-2840.

Gulden, R. H. and Shirtliffe, B.M. 2009. Weed Seed Banks: Biology and Management. Academic Press, San Diego, USA. pp. 309-328.

Melifonwu, A. A. 1994. Weeds and their control in cassava. African Crop Science Journal 2 (4): 519-530.
Njoku, P.C. 1996. The role of Universities of agriculture in appropriate manpower development for weed management in agriculture. Journal of Weed Science Society of Nigeria 9(8).

Mohler, C. L. 2001. Weed life history: Identifying vulnerabilities. pp. 40-98.

Onochie, B.E. 1975. Critical periods for weed control in cassava in Nigeria. PANS 24:292299.

Oudhia, P. 2004. Phyto-sociological studies of rainy wasterlands weed with special reference to Parthenrium hysterophous L. IN Repair District http://www.iprng.org/IPRNG

Sibuga, K. P. 1999. The role of women and children in weed management in smallholder farming systems. 17 th East African Biennial Weed Science Conference Proceedings 85-90.

Sit, A.K., Bhattacharya, M., Sarkar, B. and Aruachalam, V. 2007. Weed floristic composition in palm gardens in plains of Eastern Himalayan region of west Bengal. Current Science 2(10):1434-1439. 